\title{
Review
}

Medical Principles

and Practice

\section{Sugar Alcohol Sweeteners as \\ Alternatives to Sugar with Special Consideration of Xylitol}

\author{
Kauko K. Mäkinen \\ Institute of Dentistry, University of Turku, Turku, Finland
}

\section{Key Words \\ Sugar alcohols - Polyols - Erythritol - Xylitol - Sorbitol · \\ Dental caries - Public health $\cdot$ Sugar substitution}

\begin{abstract}
Introduction: Dental caries is a diet-associated disease which continues to be a serious health problem in most industrialized and developing countries. Strategies to maximize caries prevention should automatically consider the use of sugar substitutes. It is important that public health authorities are made cognizant of the availability of new polyol-type sugar substitutes. Review Summary: Clinical studies have shown that xylitol, a natural, physiologic sugar alcohol of the pentitol type, can be used as a safe and effective caries-limiting sweetener. Habitual use of xylitol-containing food and oral hygiene adjuvants has been shown to reduce the growth of dental plaque, to interfere with the growth of caries-associated bacteria, to decrease the incidence of dental caries, and to be associated with remineralization of caries lesions. Numerous public regulatory bodies have endorsed the use of xylitol as a caries-limiting agent. Other sugar alcohols that have been successfully used as sugar substitutes include D-glucitol (sorbitol), which, how-
\end{abstract}

ever, owing to its hexitol nature, normally has no strong effect on the mass and adhesiveness of bacterial plaque and on the growth of mutans streptococci. A tetritol-type alditol, erythritol, has shown potential as a non-cariogenic sugar substitute. Combinations of xylitol and erythritol may reduce the incidence of caries more effectively than either alditol alone. Conclusions: Partial sugar substitution with polyols is an important dietary tool in the prevention of dental caries that should be used to enhance existing fluoridebased caries prevention programmes. The most effective method of conveying this information to the public is through a proper health claim for these alditols in food labelling. The present review summarizes clinical and biochemical aspects of the above three dietary polyols and emphasizes the role of sugar substitution as a potential health-promoting strategy.

Copyright $\odot 2011$ S. Karger AG, Basel

\section{Introduction}

Following the discovery of the causal relationship between sugar consumption and caries incidence, there has been a substantial need for the promotion of sweeteners

\section{KARGER \\ Fax +4161306 1234 \\ E-Mail karger@karger.ch}

www.karger.com
C) 2011 S. Karger AG, Basel

1011-7571/11/0204-0303\$38.00/0

Accessible online at:

www.karger.com/mpp
Prof. Kauko K. Mäkinen

Institute of Dentistry, University of Turku

Lemminkäisenkatu 2

FI-20520 Turku (Finland)

Tel. +358405561 063, E-Mail kauko.makinen@uusikaupunki.fi 
that will assist in the reduction of dental caries. About 25 years ago, the 1986 Report of the Sugars Task Force published by the United States Food and Drug Administration (FDA) concluded that scientific evidence supports the conclusion that 'current average 90th percentile level of sugar [of US population groups] contribute significantly to caries experience' [1]. The report by the Task Force continued with the statement that 'the consumption of sucrose and fermentable carbohydrates facilitates the development of plaque, dental caries, and periodontal disease'. The US Surgeon General's Report on Nutrition and Health [2] in turn stated that of the 13 leading health problems, dental disorders ranked second in direct cost. A large number of authoritative reviews published before and after the FDA report have essentially reached similar conclusions.

In spite of significant advances made in its prevention, dental caries is still alarmingly prevalent in most geographic locations, making this disease of great social, medical and economic importance. It is therefore necessary that public health policy concerning oral health allow the promotion and endorsement of food ingredients which can contribute to reducing the incidence of dental caries. Strict sugar restriction over an extended period will most likely lead to caries reduction. Additional dental benefits can be achieved if sugar is replaced with safe and non-cariogenic substitutes in confectioneries and related food products. The strategy of sugar substitution should thus be considered and recommended.

The objective of this review is to summarize clinical caries trials carried out with common, simple dietary sugar substitutes, the sugar alcohols (polyols). In manufacturing and metabolic processes, these substances can be derived from their corresponding aldose sugars. Hence, such sugar alcohols can be called alditols. Since the majority of those trials have been carried out with xylitol and D-glucitol (sorbitol), the present treatise will focus on these sweeteners. Because xylitol has received the most attention during the past 40 years, special emphasis will be given to this sweetener. Xylitol is a pentitoltype molecule with special microbiologic and physicochemical properties that are assumed to contribute to caries prevention. D-Glucitol in turn is a hexitol-type bulk sweetener, its molecular structure resembling that of $\mathrm{D}$-glucose. The purpose here is also to report on available public endorsement practices of xylitol-associated limitation of dental caries in various countries. Finally, a fourcarbon member of this homologous alditol series, erythritol, will be briefly discussed owing to its great potential as a future sugar substitute of the sugar alcohol nature.
Erythritol has appeared in texts as meso-erythritol and $i$-erythritol, meso in this case standing for optical inactivity. Normally, erythritol can be used without a prefix. The simple 'ladder' structure formulas of these three alditols are shown in figure 1. Discussion of other dietary alditols, such as D-mannitol, galactitol, the arabitols, D-ribitol, and disaccharide polyols, including palatinit, maltitol and lactitol, will be presented in another context. Palatinit is an equimolar mixture of $\alpha$-D-glucopyranosyl-1,6sorbitol and $\alpha$-D-glucopyranosyl-1,6-D-mannitol, while maltitol and lactitol can be derived from maltose and lactose, respectively.

Xylitol has gained broad success in biomedical and other applications. Therefore, it is appropriate to first provide a concise overview of the uses of xylitol. This will facilitate understanding the dental health-associated position, among other medical uses, of xylitol (and other alditols). Namely, the same physicochemical, biochemical and microbiologic profiles of xylitol will rule, regardless of the target tissues and therapeutic strategies involved. Consequently, excluding purely technochemical, pharmaceutical, cosmetic and related applications, several biomedical and nutritional uses and effects of xylitol investigated during the past 40 years are shown in table 1 . The versatility of xylitol becomes immediately obvious. Among the uses shown, dental caries will thus constitute the focus of this review.

The present review was primarily designed for an audience that includes public health authorities, medical practitioners and other health care professionals who need to update their knowledge on sugar alcohol-type sugar substitutes. D-Glucitol, xylitol, and erythritol have been promoted within the dental and food sciences fields as safe and efficacious caries-limiting sugar substitutes that also exert other interesting pharmacologic effects.

\section{The Chemical Profile of Alditols}

The simple alditols are crystalline substances varying in taste from faintly sweet (galactitol) to very sweet (erythritol and xylitol, which are almost isosweet with sucrose). These molecules are characterized by the following common sugar alcohol properties:

- Absence of a reducing carbonyl group. This makes the alditol molecules chemically somewhat less reactive than the corresponding aldoses and ketoses. Some alditols thus normally avoid those chemical reactions that make many dietary hexose-based sugars acidogenic and cariogenic in human dental plaque. 
Table 1. Selected medical and nutritional uses and effects of xylitol

- Non- and anticariogenic sweetener. Latest comprehensive literature reviews: ref. 3,4

- Alleviation of xerostomia; generally recognized owing to saliva stimulation

- Decrease of Pseudomonas-based biofilm (with lactoferrin) [5]

- Prolonging of chlorhexidine effect on S. mutans [6]

- As a sweetener in diabetic diets; generally recognized [7-9]

- Energy source in infusion therapy [7]. Extensive research and application history in Germany

- Promotion of endogenous fat mobilization and oxidation [7]

- Studies as an antiulcer agent [10]

- Resuscitation from diabetic coma (early Japanese and German observations)

- Prevention of adrenocortical suppression during steroid therapy [7]

- Increase in auditory threshold values in patients with Ménière's disease $[11,12]$

- Therapy of adenosine deaminase deficiency in a form of adult myopathy [13]

- Therapy of glucose 6-phosphate dehydrogenase deficiency in red blood cells (anemia) [14]

- Restoration of heart muscle adenine nucleotide levels [15]

- Increase in the levels of retinol-binding proteins [7]

- Reduction in the incidence of liver and bile duct disorders [7]; older literature shown in ref. 16

- Stimulation of the mixed-function oxidase system [17]

- Treatment of ketonemia [18]

- Prevention of experimental osteoporosis; improvement of collagen and bone properties. Reviewed in ref. 19

- Prevention of some diabetic complications. Rat studies of Knuuttila, Svanberg, Mattila, and others reviewed in ref. 19

- As a protein-sparing and thiamine-sparing agent; stimulation of enteral vitamin synthesis $[7,20]$

- Preservation of red blood cells [21]

- Amelioration of drug-induced hemolysis [22]

- Prevention of acute middle ear infections in infants [23-25]

- Antibacterial effect on pneumococcal nasal colonization [26]

- Alleviation of cystic fibrosis condition [27]

- Stimulation of cytokine induction (rat bladder cell lines) [28]

- Reconstitution of integral membrane transport proteins [29]

- Skin care with farnesol (atopic dry skin; Staphylococcus aureus) [30]

- Prevention of cardiac arrhythmias [31]

- Stimulation of pancreatic enzyme secretion [32]

- Anti-tumor effect (increasing host cell metabolism) [33]

- Beneficial effect on the growth of broiler chicks [34]

- Prevention of phenylenediamine-induced hepatotoxicity [35]

- Wound care (inhibition of wound biofilm formation) [36]

- Inhibition of fish oil oxidation (fishy flavor suppression) [37]

- Inhibition of food spoilage micro-organisms [38]

- As a sanitizer (food safety; kitchen hygiene; with free radicals) [39]

- Removal of KL-6 mucin (around cell surface; carcinomas) [40]

- Prevention of cattle ketosis; improvement of udder health [4147]; lowering of piglet mortality [41, 48, 49] (some observations made using alditol mixtures)

Sugar Alcohols and Dental Health
- The reducing power. The sugar alcohol molecules contain 'extra' hydrogen atoms that can be deposited on other metabolites, such as coenzymes (e.g. NADP or $\mathrm{NAD}$ ), and other acceptors to generate chemically reduced products and intermediates of metabolism.

- Complexation. Owing to their polyoxy structure, alditols can form complex compounds (chelate-like structures). From the point of view of tooth mineralization, complexes with calcium ion, hereafter marked as $\mathrm{Ca}(\mathrm{II})$, are important. These complexes are not strong enough to contribute to tooth erosion or tooth demineralization. On the contrary, the presence of alditols in whole-mouth saliva and plaque fluid is believed to facilitate remineralization of caries lesions.

- Hydrophilicity. The presence of a large number of hydroxyl groups makes most alditols readily soluble in saliva. The most hydrophilic alditols, such as erythritol, xylitol, and D-glucitol, can compete with water molecules for the hydration layer of biomolecules. These reactions can strengthen the native conformation of salivary proteins and peptides.

- Free radical scavenging. Because of their polyol nature, some alditols, such a D-mannitol, xylitol and erythritol, have been investigated as potential sources of free radical scavenging activity in biological systems.

In spite of the involvement of the above common polyol properties, all alditols also exert specific selective effects on biological reactions in health and disease. It is thus erroneous to regard all alditols as exactly identical in their contributions to biological processes. The differences in the molecular masses (fig. 1) of alditols speak for the existence of important differences also between the biological properties of alditols.

Xylitol is a carbohydrate-like crystalline substance naturally occurring in low amounts in virtually all plants, micro-organisms, and animal tissues. In this alditol molecule, all five carbon atoms of the molecule bind an $\mathrm{OH}$ group (fig. 2). The xylitol molecule contains a tridentate ligand $(\mathrm{H}-\mathrm{C}-\mathrm{OH})_{3}$. It is this arrangement which reacts with various polyvalent cations and oxyacids in a most likely reversible reaction, forming the above-mentioned complexes or chelates. All simple alditols (pentitols and hexitols) contain a similar arrangement, but the stability of the complexes formed depends on the alditol and on the chemical and biological environment. It is possible that complexation between $\mathrm{Ca}(\mathrm{II})$ and xylitol plays a role in tooth mineralization (i.e. reversal of dental caries). Xylitol is roughly as sweet as sucrose. Xylitol causes a cooling effect in the mouth owing to the molecule's negative heat of solution; when crystalline xylitol is introduced in the 
Fig. 1. Simple 'ladder' structure formulas of three dietary alditol molecules discussed in the present text. The molar mass of each alditol is shown with one-decimal accuracy (in $\mathrm{g} / \mathrm{mol}$ ). The differences between the molar masses are substantial and contribute to the metabolic and physiologic fate of these molecules in the human body after ingestion.

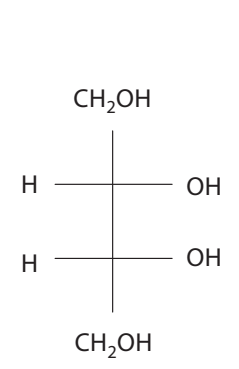

meso-erythritol

122.1

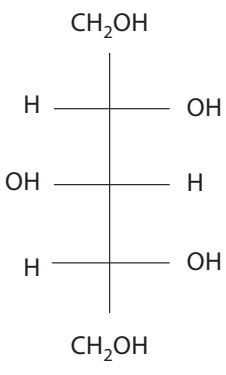

Xylitol

152.1

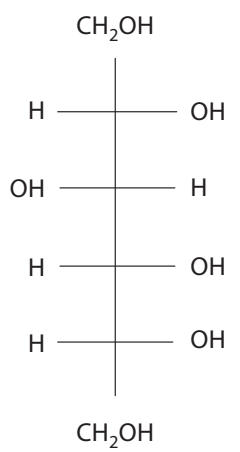

D-Glucitol (sorbitol) 182.2

Fig. 2. The xylitol molecule $\left(\mathrm{C}_{5} \mathrm{H}_{12} \mathrm{O}_{5}\right)$ shown according to 'van der Waals' contours (a), as a zig-zag structure (b), and as a three-dimensional rendering detailing the structure of a $\mathrm{Ca}$ (II)-xylitol complex (c). It has been postulated that such complexes may play a role in tooth remineralization. It is well known that these complexes facilitate the absorption of $\mathrm{Ca}(\mathrm{II})$. Reproduced with permission from author's previous articles $[4,19,53,58]$.

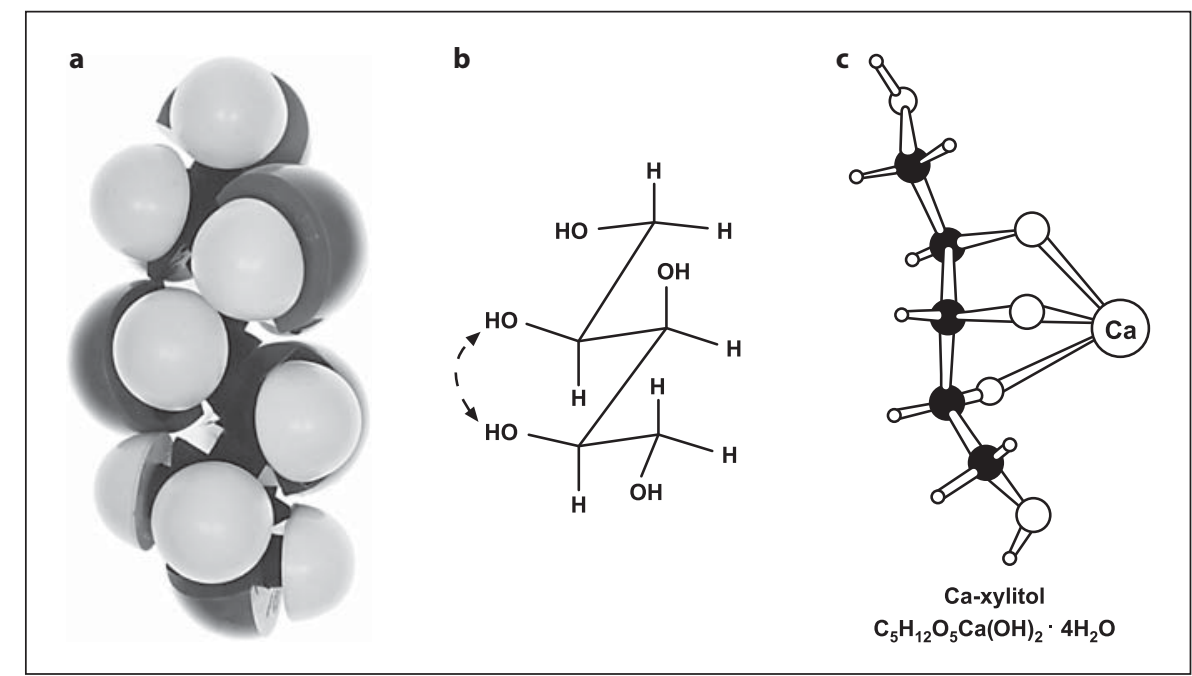

mouth, energy is required to dissolve xylitol in saliva. The required energy is taken from the environment, which produces a cooling sensation. One gram of ingested xylitol provides about two calories in human nutrition. Xylitol has been widely used as sweetener in the diets of diabetic and hyperglycemic subjects.

In the oral salivary milieu, the presence of xylitol stabilizes the calcium phosphate system of saliva, partly mimicking the function of natural salivary peptides, such as statherin and related salivary molecules, whose functions include governing the fate of $\mathrm{Ca}(\mathrm{II})$ in saliva and plaque fluid. Statherin is a 43 -amino acid polypeptide which is assumed to help provide a protective and stabilized environment for teeth. Statherin is in part responsible for the supersaturation of $\mathrm{Ca}$ (II) and inorganic phosphate levels in plaque fluid (at neutrality).
From the point of view of dental caries, however, one of the most important features of xylitol is its pentitol nature, which makes it a poor substrate for cariogenic bacteria, especially mutans streptococci. Oral biologic studies suggest that the chemical profile of xylitol plays an important role in several sialochemical and microbiological processes associated with caries limitation. Several such processes are listed in table 2.

\section{Review of Caries Trials: Effectiveness and Safety of Xylitol}

Clinical testing of xylitol commenced at the University of Turku, Finland, and resulted in a series of publications collectively called the 'Turku Sugar Studies' [62, 63]. Fig- 


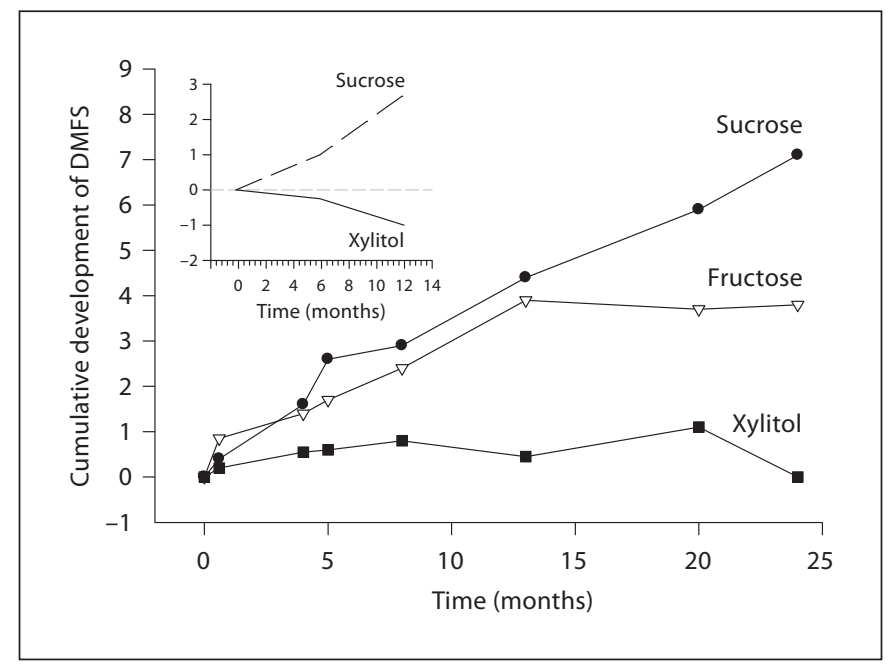

Fig. 3. Results from the first clinical caries trial on xylitol. The main plot shows the cumulative development of the decayed, missing, and filled surfaces (DMFS) index of subjects who were given sucrose-, fructose- or xylitol-containing food over 2 years. The average consumption level of xylitol was estimated as $67 \mathrm{~g}$ per day and subject during the 2 -year period. The inset shows results from a simultaneous 1-year trial where xylitol was given in the form of chewing gum. The results were compared with similar use of sucrose chewing gum. The consumption level of xylitol in this study was $6.7 \mathrm{~g}$ per day and subject (i.e. one tenth of the consumption level of the feeding study). The negative cumulative development indicates the involvement of remineralization (rehardening) of enamel caries lesions during the intervention. All data were adapted from Scheinin and Mäkinen [62] and Scheinin et al. [63], which also show the statistical evaluations.

ure 3 summarizes the most important findings of these studies. A 2-year feeding study involved relatively heavy loading with xylitol, D-fructose, and sucrose, and a 1-year trial involved the use of xylitol- or sucrose-sweetened chewing gum. The results showed that substitution of xylitol for sugar reduced caries progression. Several other trials ensued, some of which were carried out under the auspices of the World Health Organization (WHO) (table 3). The validating clinical trials thus continued in the Ylivieska studies in Finland, in the Belize studies in Central America, and in the so-called mother-child studies in Finland, Sweden and Japan. All successfully completed clinical caries trials on xylitol are shown in table 3. One of the latest trials was completed in Kuwait [81]. An example of these caries studies is shown in figure 4 . In this case, subjects used sucrose chewing gum over a period of 40 months after which a similar xylitol-sweetened gum was used for a period of 16 months. The high caries activity resulting from sucrose consumption was partly curtailed by subse-

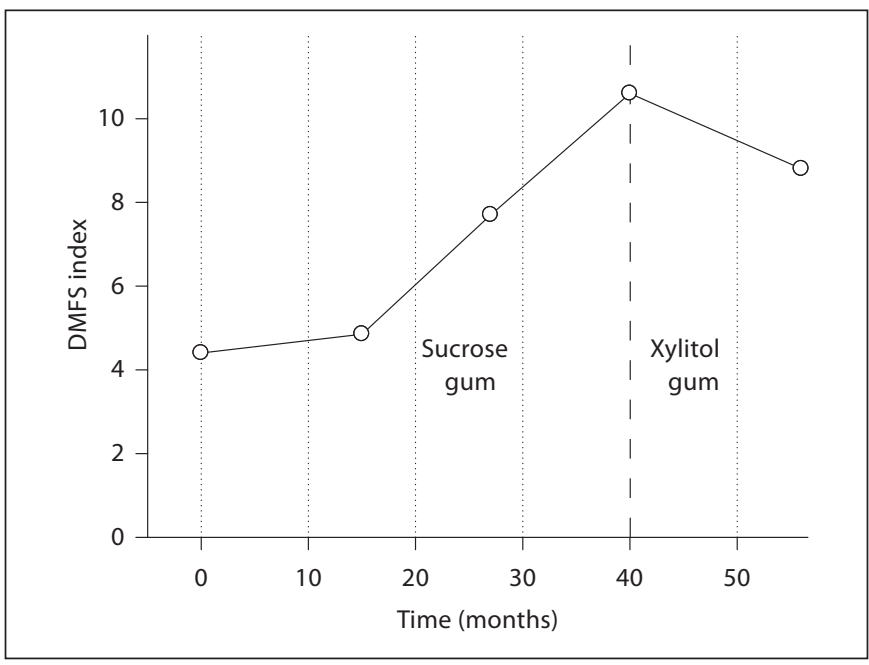

Fig. 4. Cumulative development of the DMFS index in initially 10 -year-old subjects who received sucrose chewing gum over a period of 40 months and subsequently xylitol chewing gum for 16 months. The mean consumption level of xylitol was up to $14 \mathrm{~g}$ per day and subject during the xylitol period. The annual consumption of sucrose in Belize was reported to vary between 45 and $75 \mathrm{~kg}$ per capita during the study years (1989-1993). Both study groups consumed regular sucrose diets. The index is explained in the legend to figure 3 . The declining trend of the index after 40 months suggests involvement of remineralization (rehardening) of enamel caries lesions, i.e. the $\mathrm{D}$ component of the index was significantly affected by the change of the saliva stimulant (i.e. sucrose vs. xylitol). Adapted from Mäkinen et al. [88], which also shows the statistical evaluations.

quent intense xylitol gum use. Several of the studies shown in table 3 have used chewing gum and hard caramels. The percent differences between xylitol treatments and controls shown in table 3 were regarded by the original authors as 'significant'.

The trials shown in table 3 indicated that substitution of xylitol for sugar resulted in impressive caries reduction regardless of the type of xylitol products used. As a result of the completion of the entire confirmatory rounds of testing after the first trials in Turku, all of the important original claims of the dental efficacy of xylitol have been verified by independent dental researchers in long-term clinical trials which have been conducted under varying and challenging conditions. These tests have resulted in an established consensus among scientists all over the world, including public health policymakers, suggesting that sufficient evidence exists to conclude that positive dental benefits result from the use of xylitol as a food component. These clinical trials have been reviewed in 
Table 2. Chemical and biologic properties and reactions of xylitol, and their manifestations in oral biologic processes believed to be associated with dental caries formation

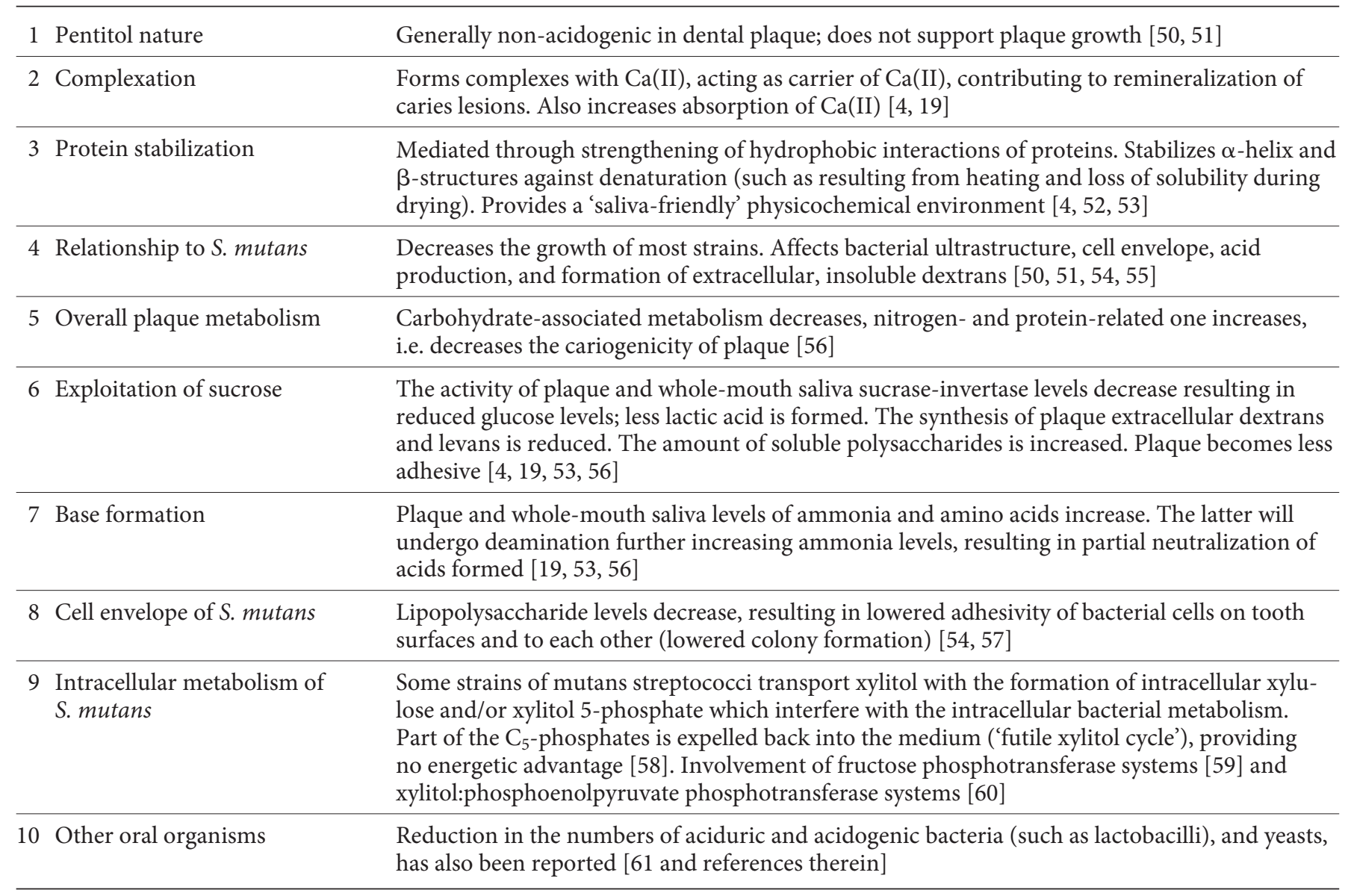

numerous contexts [e.g. 3, 4, 19]. Examples of animal experiments with xylitol and dental caries were carried out e.g. by Leach and Green [90], Shyu and Hsu [91] and Havenaar et al. [92]. Three major outcomes have resulted from the studies shown in table 3: (1) long-term protection; (2) caries prevention beyond existing preventive measures; (3) prevention of intrafamilial transmission of caries (from mother to child).

Regarding long-term protection, the Ylivieska study (table 3) involved re-examination of the subjects up to 5 years following the end of the treatment period of $2-$ 3 years (fig. 5). The subjects were born in 1970-1971 and were thus 18-19 years old at the last examination in 1989. These examinations demonstrated that the xylitol gum programme produced a long-term benefit, i.e. a significant caries-preventive effect was still observable in 1989 even though habitual xylitol chewing gum use had been discontinued several years earlier [84-86]. A long-term preventive effect was also found in one of the Belize follow-up studies [89].

Caries prevention beyond existing preventive measures was an observation based on the then-official caries prevention strategies observed in Finland during the 1970s and 1980s. The Ylivieska studies were carried out under controlled circumstances that included accepted caries prevention programmes, such as use of fluoridated toothpaste, topical fluoride application, and administration of fluoride tablets. This fluoride-based prevention was implemented under the control and recommendations of the then-State Medical Board of Finland, indicating that the overall use of fluoride did not exceed internationally accepted limits. The studies were thus performed on subjects with low or moderate caries prevalence. In spite of this, the official 'maximization' of car- 
Table 3. Summary of human caries studies on $x y l i t o l^{\mathrm{a}}$

\begin{tabular}{|c|c|c|c|c|}
\hline $\begin{array}{l}\text { Location of the } \\
\text { clinical trial }\end{array}$ & Product(s) tested & $\begin{array}{l}\text { Duration } \\
\text { years }\end{array}$ & $\begin{array}{l}\text { Dose } \\
\text { g/day }\end{array}$ & Caries reduction, comments and references \\
\hline 1 Finland (Turku) & Full diet & 2 & 67 & $>85 \%$. Compared with sucrose diet $[62,63]$. Mostly adults \\
\hline 3 Soviet Union (Kazan) & Candies & 2 & 30 & Up to $73 \%$. Compared with sucrose candies [64] \\
\hline 4 French Polynesia & Chewing gum & 3 & About 20 & 58-62\%. Compared with normal diet [65]. WHO study \\
\hline 6 Canada & Chewing gum & $1-2$ & $1.0-3.9$ & $52 \%[68]$. School programme \\
\hline 7 Finland (Ylivieska) & Chewing gum & & $7-10$ & $\begin{array}{l}30-57 \% \text {. All subjects (no-gum as control) }{ }^{\mathrm{b}}[69] \text {. School } \\
\text { programme }\end{array}$ \\
\hline 8 Finland (Ylivieska) & Chewing gum & 3 & $7-10$ & 59-84\%. High-risk subjects ${ }^{\mathrm{b}}$ [69]. School programme \\
\hline 9 Costa Rica & Dentifrice $+\mathrm{NaF}$ & 3 & Twice/day & Up to $12.3 \% .10 \% \mathrm{X}$ in the product $[70]$ \\
\hline 14 Estonia & Gum, pastilles & $2-3$ & 5 & $\begin{array}{l}50-60 \% \text {. Used on school days }{ }^{\mathrm{e}}[75] . \text { Pastille as effective as } \\
\text { gum. School programme }\end{array}$ \\
\hline 15 Finland & $\begin{array}{l}\text { Chewing gum (used by } \\
\text { mothers) }\end{array}$ & ca. 1.75 & 6 & $70 \%$ (in children). $\mathrm{NaF}$ and $\mathrm{CH}$ as control [76] \\
\hline 16 Lithuania & Chewing gum & 3 & 2.95 & $21-36 \%[77]$. Rectification of initial results $[78]^{\mathrm{f}}$ \\
\hline 17 Sweden & $\begin{array}{l}\text { Chewing gum (used by } \\
\text { mothers) }\end{array}$ & 1 & 2 & 'Significant' or $40 \%$ (in children) $[79,80]^{\mathrm{g}}$ \\
\hline 18 Kuwait & Hard caramels & 1.5 & 2.3 & $\begin{array}{l}50 \% \text {. Läkerol-type hard candies were used }[81]^{\mathrm{h}} \text {. Disabled } \\
\text { children }\end{array}$ \\
\hline 19 Finland & 'Slow-release pacifier' & 1 & $159 \mathrm{mg}$ & $\begin{array}{l}\text { No new dentinal lesions in infants [82]. A mixture of X, } \\
\text { sorbitol, and NaF was tested. The pacifier features a pocket } \\
\text { for the sweetened tablet }\end{array}$ \\
\hline
\end{tabular}

$\mathrm{CH}=$ Chlorhexidine; $\mathrm{X}=$ xylitol.

a The percent reductions of caries are in comparison with a control group that received a normal diet, sucrose products or various fluoride treatments. Non-dietary (dentifrice) studies and a programme on 'multiple preventive measures' that included the use of xylitol are also shown. The percent reductions shown were classified as 'significant' in the original papers referred to.

$\mathrm{b}$ Long-term xylitol effects (after up to 5 years of use) have been reported [84-86]. An independent follow-up study indicated that the total number of new restored surfaces was 4.0 per child in the xylitol group and 9.3 in the controls during the decade after the onset of the initial trial. Participation in the xylitol gum trial resulted in a significant reduction in the number of first restorations and hence in costs during the subsequent decade [87].

c 16 -month use of xylitol gum following the 3.3-year use (over about 40 months) of sucrose gum reduced caries significantly [88]. $<10.7$ indicates the maximum calculated, supervised use of xylitol (at school) per day and subject.

d Two-year use of xylitol gum protected erupting permanent teeth against caries, i.e. long-term effects were involved [89]. e Saliva stimulants were given only on school days (about 200 per school year). Gums were as effective as pastilles (hard candies of the 'Läkerol type'; Leaf, Inc.).

${ }^{f}$ The authors did not recognize that, in their study, xylitol gum was the only gum that lowered the DMFS increment compared with the no-gum group after 3 years. 'To still observe a significant carieslowering effect of xylitol with such a small dosage is quite remarkable' [78]. The faulty conclusions were rectified [78].

${ }^{g}$ In one literature source, the authors reported an $80 \%$ reduction between 'test and control'. When the children were 18 months old, the authors reported that 'maternal consumption of xylitol- and $\mathrm{CH}$ / xylitol-containing chewing gums significantly reduced the motherchild transmission of salivary mutans streptococci'. This study actually compared a gum with high xylitol content with gums with lower xylitol content, supplemented with either $\mathrm{CH}$ or $\mathrm{NaF}$.

${ }^{h}$ Xylitol hard candies were given only on school days (one piece of candy at a time, three times a day).

i The Läkerol Dents brand (Leaf). The products were given to the subjects with instructions 'to be used according to directions' (i.e. two pieces of hard candy three times a day). The calculated maximum consumption level of xylitol was about $4.6 \mathrm{~g} /$ day. 


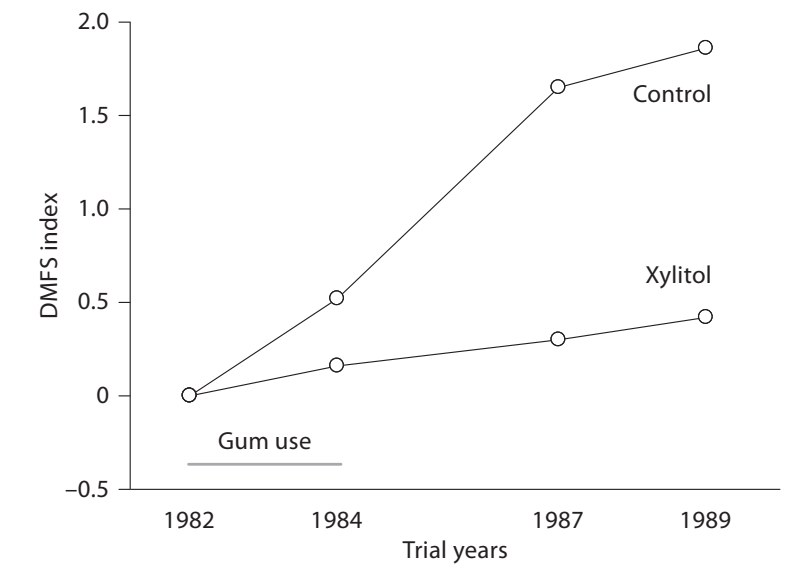

Fig. 5. Long-term effect of two-year use of xylitol gum on the development of DMFS index of young subjects initially aged 11-12 years. Xylitol gum was handed out by a school nurse, but consumption was not supervised by teachers. The consumption level of xylitol was about 7-10 g per day and subject. Control subjects did not receive xylitol gum. No xylitol gum was available to study subjects after 1984 . The results shown were obtained with participating girls. Almost similar results were obtained with boys. The purpose is to show how addition of xylitol gum to a well-administered general preventive programme affected further development of dental caries in a cohort with relatively well-controlled caries. Adapted from Isokangas et al. [69, 84-86], which also show the statistical evaluations.

ies prevention failed to provide 'maximum' protection. Introduction of xylitol gum into the programme significantly improved the degree of prevention [69].

Prevention of dental caries in children whose mothers had used xylitol during a relatively short period of the infants' life span has been considered to underline the 'transmissible and infectious' nature of dental caries [76, $79,80]$. New mother-child studies, following those completed in Finland [76], Sweden [79, 80], and Japan [93], have been initiated. Some of the trials include examination of the otitis media status of infants. 'Transmission' and 'infectivity' are terms used by authors of the above original publications.

The safety of xylitol has been thoroughly studied in humans. The worldwide scientific literature and experiences based on toxicological and nutritional studies, and long-term consumption of xylitol for dietary and diabetic purposes, support a consensus on the safety of xylitol. The safety profile of xylitol has sometimes been com- pared with that of D-glucitol. Numerous published reports confirm the comprehensive scope of xylitol safety data accumulated over the years. One example of a safety study in humans was conducted in the original Turku study [62] subjects who, during 1972-1974, consumed relatively large daily quantities of xylitol (about $67 \mathrm{~g}$ ). Several years later, in 1978, the general health status of all participants in the study was re-examined. In addition to the re-examination, a subgroup of 'chronic xylitol users' who had consumed considerable quantities of xylitol daily since 1972, were subjected to a xylitol loading test. These results can be summarized by stating that there were no pathological findings observed in blood and urine chemistry analyses, and no undesirable, long-term side-effects were found as a result of the consumption of large quantities of xylitol. These studies have been described [94] and were also included in a 1986 United States FDA-commissioned report on the safety of sugar alcohols and lactose [95]. Following the above studies, the WHO Expert Committee on Food Additives contended that 'no additional toxicological studies were recommended' [96]. Other resolutions concerning the safety of xylitol have been reviewed [97].

The voluminous literature on the role of fluorides in caries prevention has shown, on average, caries reduction percentages similar to those achieved in polyol studies (i.e. $10-60 \%$ ), with great variation depending on the source of fluoride, i.e. whether naturally present in drinking water and food, or added to water, salt, flour, dentifrices and related products. In view of the present topic, it may be more relevant to compare the effect of xylitol and fluorides when both have been used in the same study. Accordingly, the WHO field trials in Hungary [66, 67] and French Polynesia [65] showed that substitution of xylitol for sugar in confectioneries resulted in more effective caries prevention than in fluoride-using control groups, the percentage differences amounting to 38-45 and 58-62, respectively, in favour of xylitol. The recent mother-child studies showed that maternal use of xylitol gum prevented caries in infants more effectively than topical fluoride varnish treatments [76]. It is possible that combinations of fluorides and xylitol (or erythritol, vide infra) will effectively prevent dental caries.

\section{Non-Specific versus Specific Xylitol Effects}

Several studies have suggested that substitution of xylitol for sugar can lead to remineralization (rehardening) of caries lesions. Remineralization and rehardening 
are terms that have been employed to describe the type of caries arrest observed in clinical xylitol programmes and laboratory tests. Several studies suggest that xylitol can exert specific effects on dental caries not shown by hexitols. Authors who have negated the existence of specific xylitol-associated effects in caries reduction have claimed that caries reduction observed after xylitol use can be explained in terms of the following passive xylitol effects:

- Involvement of mere salivary effects, i.e. the increase in salivation associated with consumption of sweet items constitutes the only factor that explains the clinical observations made with xylitol.

- Mere partial removal of a caries-inducive agent (notably sucrose) from the diet and replacing it with an essentially non-fermentable one (xylitol) explains the observed caries reduction. In the presence of xylitol, the cariogenic organisms are thus merely deprived of their normal growth substrate. The growth of dental plaque and the progression of caries will reduce only as a result of partial removal of the cariogenic challenge.

The above passive xylitol effects naturally constitute an important aspect of xylitol-associated caries prevention and would even as such fully justify the promotion of xylitol as a caries-reducing agent. The scientific review papers and professional evaluations thus far published have not denied this fact. Scientific literature is, however, replete with observations that also support simultaneous involvement of active, specific xylitol effects that operate even in the presence of fermentable hexose-based carbohydrates, i.e. in situations where a strong cariogenic challenge is present. In the Turku Sugar Studies [62, 63], sucrose and xylitol chewing gums differed significantly from each other in their caries-limiting ability in a situation where the salivary involvement (i.e. the chewing effect) was regarded as similar in both study cohorts. The Belize studies $[72,73]$ and preceding animal experiments [90-92] also support the idea of specific xylitol effects; xylitol was found to prevent dental caries even in the presence of a strong cariogenic challenge and was more effective than D-glucitol.

Some of the physicochemical properties of xylitol mentioned above elucidate the complex scientific background that is assumed to lie behind the clinical xylitol effects reported in the literature. All dental xylitol studies have not, however, reached positive clinical and oral biologic findings. Long-term field experience has shown that in most cases failure to demonstrating such effects can be explained in terms of the following features of the studies in question:

Sugar Alcohols and Dental Health
- Use of caries-resistant study cohorts or cohorts with extremely low caries experience.

- Use of too small study cohorts.

- Use of too low concentrations of xylitol in experimental products.

- Use of too short intervention. Low caries experience presumes longer intervention.

- Use of too short or too infrequent exposure to xylitol.

- Simultaneous use of other caries-limiting agents and strategies (such as fluorides).

- Use of too insensitive analytical or diagnostic procedures.

- Use of a single analytical procedure (such as total protein or total nitrogen determination) to assess oral biologic parameters (such as plaque growth). Gravimetric, clinical (plaque index), microbiological, biochemical, and other methods should be used simultaneously. Involvement of caries-resistant study cohorts constitutes an important problem. In counties like Finland where the popular use of xylitol chewing gums nears $100 \%$ (the market share of sugar gums may currently be less than 1\%), it will be difficult if not impossible to conduct clinical caries studies on xylitol; most young subjects use xylitol habitually. If caries activity is also low, any new preventive strategy may not easily reveal its potential. Erythritol, whose chemical mechanism of action in caries prevention may drastically differ from that of xylitol, may, on the other hand, add to the efficacy of traditional prevention in populations with an even relatively wellcontrolled caries situation. It is obvious that the duration of polyol-based interventions must be increased as well.

A recommended practice is to use $6-7 \mathrm{~g}$ of xylitol daily, preferably in 3-5 separate chewing/sucking episodes, preferably after main meals and sugary snacks. Regarding oral biologic measurements such as plaque growth, plaque microbiology, and the chemical composition of saliva and plaque, experiments lasting from a few days to several months or even several years have been implemented. Regarding dental caries outcomes, trials that last several years are recommended. A particular dilemma has indeed been occasioned by studies that have been based on a single plaque assessment procedure (such as protein determination, which can lead to erroneous conclusions) since consumption of xylitol seems to increase the nitrogen- and protein-related metabolism of dental plaque while simultaneously decreasing plaque mass, volume and adhesiveness.

In addition to chewing gum, other xylitol-containing products have also been available. Some of them, along with remarks concerning their possible advantages and

Med Princ Pract 2011;20:303-320 
Table 4. Examples of xylitol-containing consumer products used in caries limitation

\begin{tabular}{lll}
\hline Product & Remarks \\
\hline 1 Chewing gum & $\begin{array}{l}\text { Renders effective mastication; salivation increases. Limited mechanical cleansing (mild plaque-reducing } \\
\text { effect); simultaneous use of fluorides and other adjuvants may increase efficacy. Drawback: unused gum } \\
\text { constitutes a refusal }\end{array}$ \\
\hline $\begin{array}{l}\text { Pastilles, tablets, } \\
\text { dragées }\end{array}$ & $\begin{array}{l}\text { Stimulation of saliva. Suitable for patients with occlusal problems. Fully soluble (no gum refuse results). } \\
\text { Concerns chewable tablets in general }\end{array}$ \\
\hline 3 Dentifrice & $\begin{array}{l}\text { Simultaneous mechanical cleansing. Normally non-caloric use (infants may swallow dentifrice); facilitates } \\
\text { several additive effects of other ingredients such as fluorides, detergents, inorganic and organic calcium } \\
\text { and phosphate salts, pharmaceuticals }\end{array}$ \\
\hline $\begin{array}{l}\text { Mouthwashes, } \\
\text { sprays, gels, } \\
\text { 'artificial saliva' }\end{array}$ & $\begin{array}{l}\text { Normally non-caloric use, normally shorter treatment time. Simultaneous use of detergents, fluorides } \\
\text { inorganic and organic salts, pharmaceuticals is possible. Gel can be used with a custom-made mouth piece } \\
\text { (effective in fissures). Saliva substitutes can be used, for example, by xerostomic patients }\end{array}$ \\
\hline 5 Pacifier & $\begin{array}{l}\text { After preliminary experiments and clinical trials, now receiving more attention as a slow-release mecha- } \\
\text { nism of xylitol dosing in infants (using a perforated nibble or a pocket in which a xylitol tablet can be in- } \\
\text { serted for gradual dissolution by saliva). Simultaneous positive impact on middle ear infection control, } \\
\text { resulting in decreased antibiotic prescription }\end{array}$ \\
\hline
\end{tabular}

disadvantages, are shown in table 4 . Special patient groups may benefit from the use of xylitol. Examples of such cohorts are shown in table 5 .

\section{Synergism between Xylitol and Other Dental Health Adjuvants}

The ability of various physical and chemical agents to enhance their effects when they are applied simultaneously with each other is well known. An early observation on reduced salivary fluorine levels determined with a fluoride-sensitive electrode in the whole-mouth saliva of xylitol-consuming subjects and an opposite trend in the saliva of sucrose-consuming subjects [56; table XI of the paper] prompted the present author to predict, at the turn of the 1970s and 1980s, that there might be a synergistic effect of ionizable fluorine ('fluoride') and xylitol in caries limitation (published as part of commercial advertising of the then-Xyrofin AG, Bar, Switzerland). Although this assumption met criticism, it was considered plausible owing to the complexation between xylitol and metal cations (including calcium, see above); interaction between xylitol and fluoride (or at least concerning their effects on caries-inducive bacteria and reactions with hydroxyapatite) was regarded as a possibility. Synergism was possible also owing to the known affinity between $\mathrm{Ca}(\mathrm{II})$ and $\mathrm{F}^{-}$. The fluoride ion may turn out to be ineffective under cer- tain conditions: Hamilton and Ellwood [98] suggested that Streptococcus mutans (strain Ingbritt) possesses at least two glucose transport systems, one of which is relatively fluoride insensitive. It would be necessary to investigate the effect of added xylitol on these transport systems.

Further indirect or partly direct indications of synergy between the effects of anti-plaque agents and $\mathrm{F}^{-}$on enamel demineralization can also be found in Arends et al. [99], Luoma et al. [100] and Meurman [101].

In 1992, Rogers and Bert [102] published their study on the cells of $S$. mutans that were pulsed with either $\mathrm{D}$-glucose or xylitol under $\mathrm{pH}$ free-fall conditions. Fluoride had little effect on the response of the organism to D-glucose until the culture $\mathrm{pH}$ fell to about 5.0, at which point lactic acid production was reduced about threefold. The effect of xylitol was most marked in the presence of fluoride, i.e. the $\mathrm{pH}$ did not fall below 5.0 and only $50 \%$ of added D-glucose was utilized. The authors suggested that xylitol augmented the metabolic effects on S. mutans of low levels of fluoride. About 13 years later, Maehara et al. [103] published their revealing experiments on synergistic inhibition by combination of fluoride and xylitol on glycolysis by mutans streptococci. In these studies, cells of S. mutans NCTC10449 and S. sobrinus 6715 were tested for acid production from D-glucose under anaerobic conditions in the presence of 0-6.4 $\mathrm{mM} \mathrm{F}^{-}$and/or $60 \mathrm{mM}$ xylitol. Their combination inhibited acid production 
Table 5. Consumer groups that may benefit from the use of xylitol-containing oral care products

\begin{aligned} & \hline 1 $\begin{array}{l}\text { Expectant mothers and mothers during children's first years of life. Other family members and nurse- } \\ \text { maids in intimate contact with infants }\end{array} \\ &$\hline 2 Children attending day-care centres and kindergartens (emphasis on early caries prevention) \\ & \hline 3 Elderly subjects (gum products may be replaced by pastilles, lozenges, dragées) \\ & \hline 4 Orthodontic patients. Xylitol gums that do not damage orthodontic appliances are available \\ & \hline 6 Certain workers (at bakeries, and confectionary and car battery factories) \\ & \hline 7 Dryletes (sports beverages may contain Ca-chelating fruit acids and fermentable sugars). Prolonged \\ & \hline 8 Disabled subjects. Disabilities may include mental problems, lack of dexterity, and other disabilities \\ & \hline 9 $\begin{array}{l}\text { Hospital patients. In long-term hospitalization, care should be taken to avoid causing oral health prob- } \\ \text { lems by restricting the administration of sugary medication }\end{array} \\ &$\hline 10 Patients with impaired glucose tolerance \\ & \hline 11 Diabetic and hyperglycemic subjects \\ & \hline 12 Patients with allergies to certain cereal products (starch syrups may contain traces of wheat) \\ & \hline 13 Patients with regurgitation (frequent regurgitation may cause dental erosion) \\ & \hline\end{aligned}

more effectively than $\mathrm{F}^{-}$or xylitol alone. In the presence of both agents, the production of lactic acid decreased while that of acetic acid and formic acid increased. It was suggested that xylitol inhibited the 'upper' part of the glycolytic pathway, while $\mathrm{F}^{-}$inhibited the 'lower' part.

Additional support to the above concept was obtained in the theoretical evaluations of Petin et al. [104]. They presented a mathematical model to describe, optimize and predict a synergistic interaction between fluoride and xylitol on acid production of mutans streptococci. The model suggests that synergism is caused by the additional effective damage arising from an interaction of sublesions induced by each agent; the sublesions are considered ineffective when each agent is used individually.

Other studies have shown that usage of xylitol prolonged the effect of chlorhexidine therapy on oral mutans streptococci [6], suggesting that an enhancing effect of xylitol was involved. The findings of Kim et al. [105] suggested that cationic peptides alone or in combination with chlorhexidine or xylitol might prove effective for the inhibition of the growth of cariogenic streptococci. The peptides included gaegurin 6 , an animal-derived cationic peptide, and two of its derivatives. Synergy between the effects of chlorhexidine and xylitol was also discovered in the studies of Decker et al. [106]. In another dental field, observations such as those by Han et al. [107] demonstrating xylitol to inhibit inflammatory cytokine expression induced by Porphyromonas gingivalis deserve attention. It is possible that new studies will disclose several synergistic effects of dental health adjuvants.

Synergy between oral health adjuvants and oral micro-organisms is not in any way unusual. Numerous examples, in addition to the above xylitol-associated instances, have been published. Sanguinarine and $\mathrm{Zn}$ (II) exhibited synergism in their effects on oral streptococci and Actinomyces species [108]. Sanguinarine (pseudochelerythrine) can be derived from Sanguinaria canadensis and other Papaveracea species. Chlorhexidine and $\mathrm{Cu}$ (II) exerted a synergistic, growth-inhibitory effect on S. mutans, Actinomyces viscosus and Actinomyces näslun$d i$, the streptococcus displaying the highest sensitivity [109].

Partially related to synergy is the way that bacterial transport can concern xylitol and D-fructose. Laboratory experiments at Turku Dental School in the late 1970s revealed that, in the presence of $\mathrm{D}$-fructose, the cells of S. mutans (strain Ingbritt) altered the response to xylitol: $\mathrm{pH}$ of cultures decreased and the cells grew well. Subsequent research showed that both substances can share the same transport mechanism. Expression of two genes of 
Table 6. Consequences of cohesive and coherent public health measures accomplished in one nation

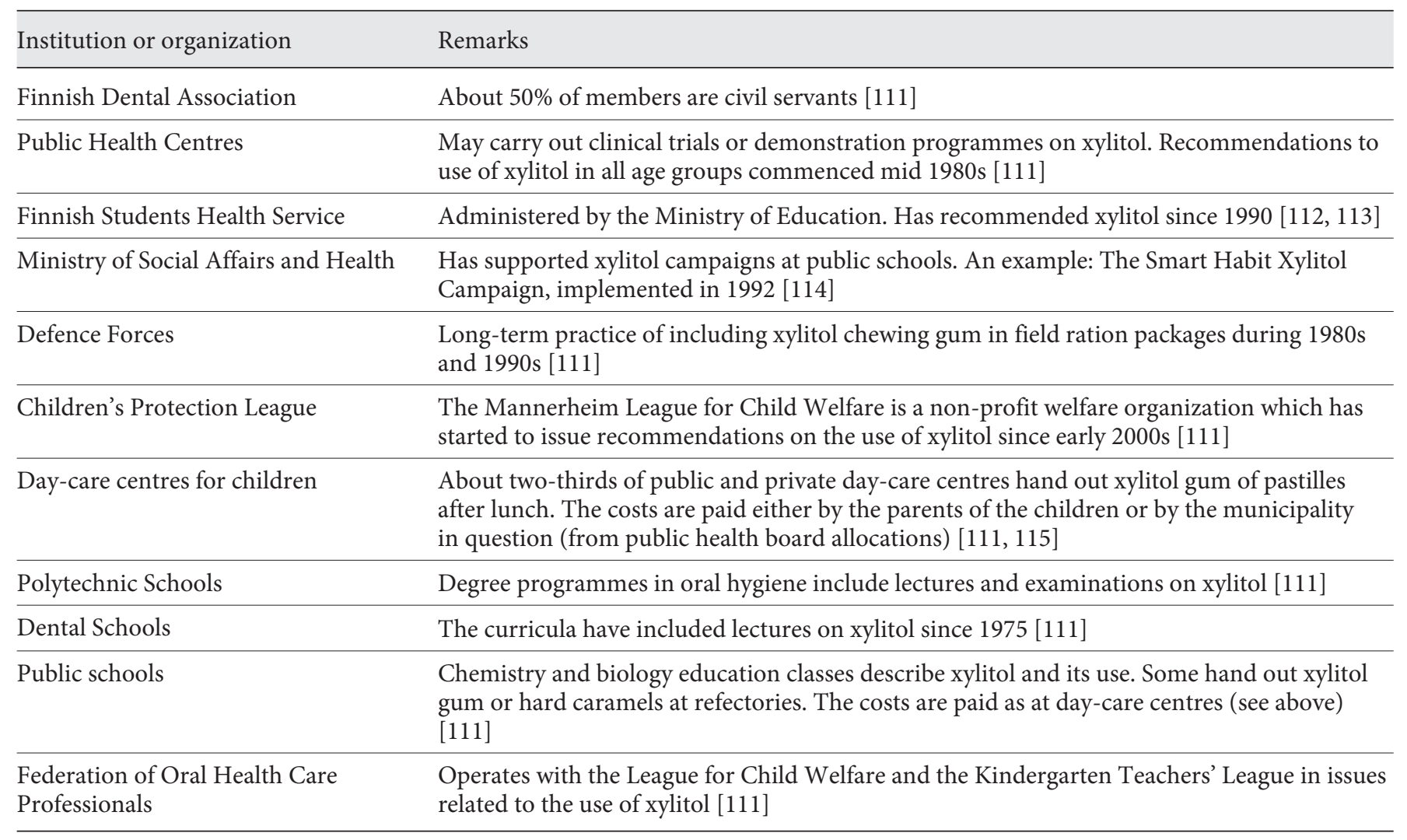

Examples of Finnish public institutions, regulatory bodies and professional organizations which endorse or recommend the use of xylitol in caries prevention. The list illustrates the multitude of publicly supported caries prevention strategies made possible in a typical prevention-oriented society. The information shown was received in 2006 by personal communication from the respective associations and agencies, or abstracted from news media and professional trade magazines in 2006 [111], and re-checked in May 2010.

Arabidopsis thaliana pollen and xylem cells in Saccharomyces cerevisiae revealed that these proteins catalyze the energy-dependent, high-capacity transport of D-fructose and xylitol [110]. Consequently, the same D-fructosexylitol-utilizing mechanism seems to be present in plants and micro-organisms. These findings also suggest that combinations of xylitol and D-fructose should not be used in confectioneries or other food items; their habitual use may increase the incidence of caries. However, no long-term clinical study has investigated the caries activity of subjects receiving mixtures of xylitol and D-fructose. A preliminary 5-day study carried out in the early 1970 s at this laboratory indicated that a 50:50 mixture of xylitol and D-fructose reduced plaque growth almost to the same extent as xylitol alone.

\section{Public Health Evaluation of Xylitol}

It is imperative that public health policy concerning oral health allows the promotion of food and food components that can assist in reducing oral diseases. Clinical studies have demonstrated that the use of xylitol sweetener in oral care gum products can significantly reduce the incidence of dental caries and may also alleviate gingival and periodontal infections. Public health evaluation of xylitol-containing gum products has been carried out during the past 30 years. This evaluation process has resulted in recommendations for use of xylitol in publicly supported caries prevention programmes. Endorsing organizations have included professional dental associations, non-profit organizations and government departments. Notably, Finnish public health centres have participated in the dissemination of xylitol-related infor- 
Table 7. Public institutions, regulatory bodies, and professional organizations that have endorsed or recommended the use of xylitol chewing gum in caries prevention

\begin{tabular}{|c|c|}
\hline Organization & Countries \\
\hline $\begin{array}{l}\text { National Dental } \\
\text { Association }\end{array}$ & $\begin{array}{l}\text { Canada, Finland, Estonia, France, } \\
\text { Hungary, Iceland, Ireland, Malta, Norway, } \\
\text { Peru, South Africa, South Korea, Switzer- } \\
\text { land, Sweden, Taiwan, The Netherlands, } \\
\text { Turkey, United Kingdom, USA }\end{array}$ \\
\hline Ministry of Health & Finland, Italy, Japan \\
\hline $\begin{array}{l}\text { Other Dental } \\
\text { Associations }\end{array}$ & $\begin{array}{l}\text { China (National Committee for Oral } \\
\text { Health), Japan (School Dentists' Associa- } \\
\text { tion), United Kingdom (British Dental } \\
\text { Health Foundation), Switzerland ('Tooth- } \\
\text { friendly' Sweets International) }\end{array}$ \\
\hline Armed Forces & Finland, USA \\
\hline Other organizations & $\begin{array}{l}\text { Germany (German Consumers' Founda- } \\
\text { tion), The Netherlands (Ivory Cross), } \\
\text { Scotland (The Scottish Intercollegiate } \\
\text { Guidelines Network), World Health } \\
\text { Organization }\end{array}$ \\
\hline
\end{tabular}

mation to patients (table 6). Nordblad et al. [114] and Honkala et al. $[116,117]$ have published surveys on the consumption pattern of xylitol chewing gum among Finnish adolescents. Since the mid-1970s, these subjects have made up a young cohort that has engaged - even when viewed globally - in the most habitual use of xylitol gum as part of a caries prevention strategy. Table 7 in turn gives examples of institutions that have recommended the use of xylitol chewing gum in caries prevention in various other countries. Emphasis is here on xylitol since it is, at this stage, the only bulk sweetener present in oral care gums that has earned world-wide public recommendations as a caries-limiting agent.

\section{Results from Caries Trials on D-Glucitol (Sorbitol)}

Clinical caries trials carried out on D-glucitol are summarized in table 8 . Some earlier studies suffered from scant information on experimental details, such as the consumption level of D-glucitol. In some studies, the chewing episodes of D-glucitol-containing gum exceeded $5 \mathrm{~min}$, extending even up to $30 \mathrm{~min}$ in some trials. In most other successfully completed later trials 5-min chewing has been found to provide more meaningful re- sults (owing to the possibility that prolonged salivation may mask desired pharmacologic alditol-based direct effects). Nevertheless, it is self-evident that D-glucitol has significantly reduced the incidence of caries when compared with sucrose. When compared with xylitol, the efficacy seems to be weaker. This may be understandable against the known microbiologic and molecular parameters of D-glucitol, which normally stimulates the growth of some strains of mutans streptococci, normally has no effect on the growth of dental plaque, and is, by virtue of its 'glucose-polyol nature', readily convertible to glucose and fructose which can serve as substrates of cariogenic, plaque-building organisms in dental plaque. Mixtures of xylitol and D-glucitol do exert positive dental effects. Studies have shown that the more xylitol the mixtures contain, the stronger the caries reduction. At the same time, more significant decrease of plaque mass and more distinct lowering of oral counts of cariogenic bacteria have been observed. Studies have also suggested that human dental plaque can become adapted to D-glucitol.

\section{Erythritol, a Potential Sugar Substitute}

Erythritol is a natural sugar alcohol of the tetritol type, indicating that the molecule has four hydroxyl groups. Erythritol has been approved for use in the United States and throughout much of the world. The non-cariogenicity of erythritol was first investigated in rats [124]. Based on the determination of the presence of risk factors (especially dental plaque mass and growth of mutans streptococci), erythritol has been regarded as non-cariogenic in humans [124-127]. Erythritol seems to inhibit the growth of certain mutans streptococci strains by a mechanism that differs from that of xylitol (fig. 6). Normally, xylitol-associated inhibition of growth appears throughout the growth. Erythritol also inhibits the growth of mutans streptococci. As figure 6 shows, the growth of S. mutans $267-S$ was most distinctly affected by erythritol during later growth phases. Figure 6 represents a case with insignificant growth inhibition caused by xylitol; normally, xylitol displays effective growth inhibition of several other oral streptococci. These results also suggest that certain combinations of erythritol and xylitol may turn out to be potentially caries limiting. The gastro-intestinal tolerability of erythritol even in infants and its essentially non-caloric or low-caloric use in human nutrition suggest that erythritol should be subjected to longterm caries studies in humans. 
Fig. 6. Selectivity of the effect of simple dietary alditols and maltitol on the growth of the cells of $S$. mutans (strain 267-S) in the presence of $6 \%$ alditols. a Effect of alditol concentration on growth. b Effect of $6 \%$ alditol on growth as a function of incubation time. Note that the molar concentrations of $6 \%$ alditols differ to a certain extent. Part of the data was abstracted from Mäkinen et al. [127], which also shows the statistical evaluations.

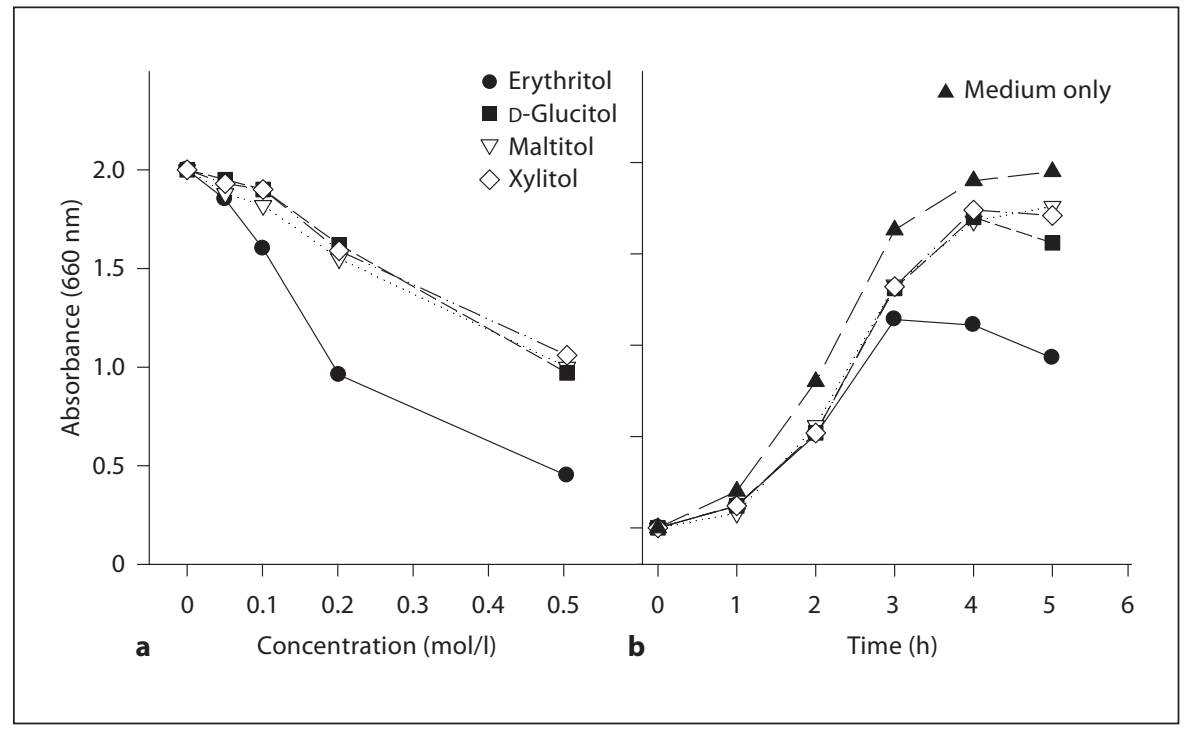

Table 8. Summary of human caries trials on D-glucitol (sorbitol) ${ }^{\mathrm{a}}$

\begin{tabular}{|c|c|c|c|c|}
\hline $\begin{array}{l}\text { Study } \\
\text { location }\end{array}$ & Product(s) tested & $\begin{array}{l}\text { Duration } \\
\text { years }\end{array}$ & $\begin{array}{l}\text { Dose } \\
\text { g/day }\end{array}$ & Caries reduction \\
\hline England & Tablets vs. normal diet & 2 & Not given & 'Small but insignificant benefit' [118] \\
\hline Denmark & Chewing gum vs. normal diet ${ }^{\mathrm{b}}$ & 2 & 3.6 & $10 \%[119]$ \\
\hline Sweden & Lycasin $^{\circledR}$ candies vs. sucrose ${ }^{c}$ & Up to 2.5 & Not given & $25 \%$ (the authors were cautious as to results) [120] \\
\hline $\begin{array}{l}\text { USA (Boston, } \\
\text { Mass.) }\end{array}$ & Chewing gum vs. normal diet & 2 & Not given (2 sticks) & Not signifcant (quote) [122] \\
\hline Hungary & Chewing gum vs. normal diet & 2 & Not given $(2 \text { sticks })^{\mathrm{d}}$ & $33-39 \%[123]$ \\
\hline Belize & $\begin{array}{l}\text { Chewing gum, } \\
\text { permanent teethe, } \\
\text { deciduous teeth }^{\mathrm{e}}\end{array}$ & $\begin{array}{l}3.3 \\
2\end{array}$ & $\begin{array}{l}<10.7^{f} \\
<10.7^{f}\end{array}$ & $\begin{array}{l}45 \%[72] \\
30-40 \%[73]\end{array}$ \\
\hline
\end{tabular}

a Two studies that possibly employed D-glucitol chewing gum have been omitted from the list owing to defective reporting. One study that employed D-glucitol was omitted because of inclusion of a nugatory number of test subjects.

b The saliva stimulant used contained $45 \mathrm{mg}$ 'calcium phosphate' per each chewable item which the authors called variably 'gum' or 'tablet' (the gum base reportedly being one ingredient in both, however).

c This study can be included under D-glucitol studies for convenience; the Swedish Lycasin ${ }^{\circledR}$ used reportedly contained about
$8 \%$ D-glucitol (and 8\% maltitol, the rest consisting of tri- to pentasaccharides and higher alcohols).

$\mathrm{d}$ The gum was reported to contain ' $65 \%$ polyols (D-glucitol and D-mannitol)', with a chewing time of 'at least 20 min' (i.e. the study, in essence, predominantly investigated the effect of chewing).

e Chewing time: 5 min (concerns supervised use at schools; other usage, unsupervised).

$\mathrm{f}^{\mathrm{f}}<10.7$ indicates that the maximum calculated, supervised usage on school days was $10.7 \mathrm{~g}$ per day and per subject. 
Several caries trials on erythritol have begun. At this stage, there is not enough evidence to rank simple dietary alditols as caries-preventative agents. It has been suggested, however, that the caries-limiting efficacy in humans may follow the homologous alditol series, and may thus depend on the number of hydroxyl groups present in the alditol molecule $[4,128]$. The efficacy may decrease as follows: erythritol $\geq$ xylitol $>$ D-glucitol. It is obvious that the same special patient groups that may benefit from the use of xylitol (table 5) can also profit from erythritol.

\section{Conclusions}

Several alditol-type sugar alcohols have been used in medical, nutritional, cosmetic and numerous other applications. Examples of alditols which have achieved remarkable utility value include D-glucitol (sorbitol), D-mannitol, xylitol, and more recently, erythritol. Several long-term clinical studies have been carried out on the relationship between dental caries and the consumption of xylitol, which is a pentitol-type alditol. All clinical studies consistently point in the same direction, i.e. the use of relatively small daily amounts of xylitol significantly reduces the incidence of dental caries. The accumulated scientific evidence demonstrates that xylitol meets the safety and efficacy prerequisites for use in caries prevention programmes in all age groups. Owing to the importance of early caries prevention, xylitol programmes in schools have been regarded as especially important in demonstrating that also long-term protection against caries infection can result from habitual use of xylitol. Notably chewable xylitol products (chewing gums, lozenges, troches, and hard caramels) have turned out to be useful. So-called mother-child studies have suggested that maternal use of xylitol can prevent dental caries in infants although the latter have not received xylitol. This is based on the ability of xylitol to prevent intrafamilial transmission of caries-inducive mutans streptococci. The xylitol molecule, owing to its pentitol nature, has been shown to reduce the mass and adhesiveness of dental plaque and to resist the so-called acid attack resulting from consumption of common hexose-based dietary sweeteners (notably sucrose). Hexitols (D-glucitol and D-mannitol), owing to their hexose-based structure, tend to support the growth of dental plaque and multiplication of mutans streptococci although their metabolism in plaque does not normally lead to strong acid production.
In preliminary laboratory studies, a lower homologue of the alditol series, erythritol, has shown significant promise as a sugar substitute. Combinations of xylitol and erythritol may turn out to reduce the incidence of caries more strongly than either alditol alone. This proposition should provide impetus for new clinical studies.

The addition of xylitol (and possibly erythritol) programmes to existing prevention strategies can bring considerable cost savings in health care allowances, reduce pain and decrease work loss. Because dental caries has been identified by health authorities as a significant public health problem, it is essential that the public be informed about the beneficial effects of xylitol (and most likely erythritol) on dental health. Since there is currently significant scientific information on xylitol as a cariesreducing sugar substitute, it is understandable that the utility value of xylitol and its vehicles for public health needs has recently received attention among leading experts in the field [129-131].

Problems in the interpretation of results from clinical trials and laboratory experiments with xylitol may arise from faults in study design. Xylitol functions predictably in caries prevention provided that certain basic requirements are considered when planning trials, demonstration programmes and factual prevention strategies. The dosage and frequency of use of xylitol, the duration of intervention and the use of study cohorts with sufficiently high caries activity (i.e. cohorts which are indeed 'afflicted with the disease') may be expected to result in positive findings. Study subjects with extremely low caries prevalence may not be suited to this type of demonstration. The same precautions also apply to future studies with erythritol.

References

1 Glinsmann WH, Irausquin $\mathrm{H}$, Park YK: Evaluation of health aspects of sugars contained in carbohydrate sweeteners. Report of Sugars Task Force. J Nutr 1986;116:S1-S216.

2 US Department of Health and Human Services. The Surgeon General's report on nutrition and health. DHHS (PHS) Publ 1988, No 88-50211.

3 Milgrom P, Zero DT, Tanzer JM: An examination of the advances in science technology of prevention of tooth decay in young children since the Surgeon General's Report on Oral Health. Acad Pediatr 2009;9:404-409.

4 Mäkinen KK: Sugar alcohols, caries incidence, and remineralization of caries lesions: a literature review. Int J Dent 2010;2010: 981072 . 
5 Ammons MC, Ward LS, Fisher ST, Wolcott $\mathrm{RD}$, James GA: In vitro susceptibility of established biofilms composed of a clinical wound isolate of Pseudomonas aeruginosa treated with lactoferrin and xylitol. Int J Antimicrob Agents 2009;33:230-236.

6 Hildebrandt GH, Sparks BS: Maintaining mutans streptococci suppression with xylitol chewing gum. J Am Dent Assoc 2000;131: 909-916.

7 Georgieff M, Moldawer LL, Bistrian BR, Blackburn GL: Xylitol, an energy source for intra-venous nutrition after trauma. J Parenter Enteral Nutr 1985;9:199-209.

-8 Bässler KH, Prellwitz W, Unbehaun V, Lang K: Xylitstoffwechsel beim Menschen: zur Frage der Eignung von Xylit als Zucker-Ersatz beim Diabetiker. Klin Wochenschr 1962;40:791-793.

-9 Natah SS, Hussien KR, Tuominen JA, Koivisto VA: Metabolic response to lactitol and $x y-$ litol in healthy men. Am J Clin Nutr 1997;65: 947-950.

10 Assouline G, Danon A: Hyperosmotic xylitol, prostaglandins and gastric mucosal barrier. Prostaglandin Med 1981;7:63-70.

- 11 Palchun VT, Aslamazova VI, Buyanovskaya OA, Polyakova TS: Employment of xylit for intralabyrinthine hydropsy detection. Vestn Otorinolaringol 1982;4:35-38 (in Russian).

12 Palchun VT: Diagnostic informativity of the drugs used to reveal intralabyrinthine hydrops according to the data of audiologic and biochemical studies. Zh Ushn Nos Gorl Bolezn 1983;43:27-31 (in Russian).

13 Bruyland M, Ebinger G: Beneficial effect of a treatment with xylitol in a patient with myoadenylate deaminase deficiency. Clin Neuropharmacol 1994;17:492-493.

14 Van Eys J, Wang YM, Chan S, Tanphaichitr VS, King SM: Xylitol as a therapeutic agent in glucose-6-phosphate dehydrogenase deficiency; in Sipple HL, McNutt KW (eds): Sugars in Nutrition. New York, Academic Press, 1974, pp 613-631.

-15 Zimmermann HG, Gerlach E: Stimulation of myocardial adenine biosynthesis by pentoses and pentitols. Pflügers Arch 1978;376: 223.

16 Mäkinen KK: Biochemical Principles of the Use of Xylitol in Medicine and Nutrition with Special Consideration of Dental Aspects. Basel, Birkhäuser, 1978 (also Experientia Suppl 1978;30:1-160).

17 Smith JT: Effect of xylitol feeding on the mixed function oxidase system. Nutr Rep Int 1982;26:347-353.

\18 Touissant W, Roggenkamp K, Bässler KH: Behandlung der Ketonämie im Kindesalter mit Ksylit. Z Kinderheilk 1967;98:146-154.

$\checkmark 19$ Mäkinen KK: Can the pentitol-hexitol theory explain the clinical observations made with xylitol? Med Hypotheses 2000;54:603613.
20 Rofe AM, Krishnan R, Bais R, Edwards JB, Conyers EAJ: A mechanism for the thiamine-sparing action of dietary xylitol in the rat. Aust J Exp Biol Med Sci 1982;60:101-111.

21 Quadflieg KH, Brand K: Carbon and hydrogen metabolism of xylitol and various sugars in human erythrocytes. Hoppe-Seyler's Z Physiol Chem 1978;359:29-36.

22 Ukab WA, Sato J, Wang YM, van Eys J: Xylitol mediated amelioration of acetylphenylhydrazine-induced hemolysis in rabbits. Metabolism 1981;30:1053-1059.

23 Uhari M, Kontiokari T, Koskela M, Niemelä M: Xylitol chewing gum in prevention of acute otitis media: double blind randomised trial. Br Med J 1996;313:1180-1184.

24 Uhari M, Kontiokari T, Niemelä M: A novel use of xylitol sugar in preventing acute otitis media. Pediatrics 1998;102:879-884.

25 Uhari M, Tapiainen T, Kontiokari T: Xylitol in preventing acute otitis media. Vaccine 2000;19(suppl 1):S144-S147.

-26 Kontiokari T, Svanberg M, Mattila P, Leinonen M, Uhari M: Quantitative analysis of the effect of xylitol on pneumococcal nasal colonisation in rats. FEMS Microbiol Lett 1999;178:313-317.

27 Zabner J, Seiler MP, Launspach JL, Karp PH, Kearney WR, Look DC, Smith JJ, Welsh MJ: The osmolyte xylitol reduces the salt concentration of airway surface liquid and may enhance bacterial killing. Proc Natl Acad Sci USA 2000;97:11614-11619.

28 Abolhassani M, Wertz X, Pooya M, Chaumet-Riffaud P, Guais A, Schwartz L: Hyperosmolarity causes inflammation through the methylation of protein phosphatase $2 \mathrm{~A}$. Inflamm Res 2008;57:419-429.

-29 Ambudkar SV, Maloney PC: Bacterial anion exchange. Use of osmolytes during solubilization and reconstitution of phosphatelinked antiport from Streptococcus lactis. J Biol Chem 1986;261:10079-10086.

30 Katsuyama M, Kobayashi Y, Ichikawa H, Mizuno A, Miyachi Y, Matsunaga K, Kawashima M: A novel method to control the balance of skin microflora. 2. A study to assess the effect of a cream containing farnesol and xylitol on atopic dry skin. J Dermatol Sci 2005;38:207-213.

31 Yoshimura N, Yamada H, Haraguchi M: Anti-arrhythmic effect of xylitol during anesthesia. Masui 1979;28:841-848 (in Japanese with English summary).

32 Vainshtein SG, Pivikova MI, Maksudova D: Xylitol action on the gastric secretion and the external secretory function of the pancreas in patients with duodenal ulcer. Vopr Pitan 1973;1:14-17 (in Russian).

33 Sato J, Wang YM, van Eys J: Metabolism of xylitol and glucose in rats bearing hepatocellular carcinomas. Cancer Res 1981;41:31923199.

34 Takahashi K, Mashiko T, Akiba Y: Effect of dietary concentration of xylitol on growth in male broiler chicks during immunological stress. Poult Sci 2000;79:743-747.
35 Sood C, Khan S, O’Brien PJ: Phenylenediamine induced hepatocytes cytotoxicity redox. Cycling mediated oxidative stress without oxygen activation. Biochim Biophys Acta 1997; 1335:343-352

36 Dowd SE, Sun Y, Smith E, Kennedy JP, Jones CE, Wolcott R: Effects of biofilm treatments on the multi-species Lubbock chronic wound biofilm model. J Wound Care 2009; 18:508-512.

37 Faraji H, Lindsay RC: Characterization of antioxidant activity of sugars and polyhydric alcohols in fish oil emulsions. J Agric Food Chem 2004;52:7164-7171.

38 Mäkinen KK, Söderling E: Effect of xylitol on some food-spoilage microorganisms. J Food Sci 1981;46:950-951.

39 Kwon NH, Kim SH, Kim JY, Lim JY, Kim JM, Jung WK, Park KT, Bae WK, Noh KM, Choi JW, Hur J, Park YH: Antimicrobial performance of alkaline ionic fluid (GC-100X) and its ability to remove Escherichia coli O157:H7 from the surface of tomatoes. J Food Protect 2003;66:1604-1610.

40 Guo Q, Tang W, Inagaki Y, Kokudo N, Sugawara Y, Karako H, Nakata M, Makuuchi M: Subcellular localization of KL-6 mucin in colorectal carcinoma cell lines: association with metastatic potential and cell morphology. Oncol Rep 2007;17:1057-1060.

41 Mäkinen KK, Hämäläinen M, Tuori M, Poutiainen E: A polyol mixture in the diet of dairy cows. Nutr Rep Int 1981;23:1077-1087.

42 Poutiainen E, Tuori M, Sirviö I: The fermentation of polyalcohols by rumen microbes in vitro. Proc Nutr Soc 1976;35:140A-141A.

-43 Korhonen H, Rintamäki O, Antila M, Tuori $\mathrm{M}$, Poutiainen E: A polyol mixture or molasses treated beet pulp in the silage based diet of diary cows. II. The effect on the lactoperoxidase and thiocyanate content of milk and the udder health. J Sci Agric Soc Finl 1977; 49:330-345.

44 Hamada T, Ishii T, Taguchi S: Blood changes of spontaneously ketotic cows before and after four hours after administration of glucose, xylitol, 1,2-propanediol, or magnesium propionate. J Dairy Sci 1982;65:1509-1513.

45 Sakai T, Hamakawa M, Kubo S: Glucose and xylitol tolerance tests for ketotic and healthy dairy cows. J Dairy Sci 1996;79:372-377.

46 Mizutani H, Sako T, Toyoda Y, Fukuda H, Urumuhang N, Koyama H, Hirose $\mathrm{H}$ : The intravenous xylitol tolerance test in non-lactating cattle. Vet Res Commun 2003;27:633-641.

47 Toyoda Y, Sako T, Mizutani H, Sugiyama M, Hayakawa N, Hasegawa H, Hirose H: A bolus infusion of xylitol solution in the treatment of cow ketosis does not cause a surge in insulin secretion. J Vet Med Sci 2008;70:1091-1093.

48 Näsi M, Alaviuhkola T: Polyol mixture supplementation in the diet of breeding sows and piglets. J Sci Agric Soc Finl 1980;52:5058. 
-49 Näsi M, Alaviuhkola T: Polyol mixture supplementation as a sweetener and/or feed additive in the diet of piglets. J Sci Agric Soc Finl 1981;53:57-63.

50 Tanzer J: Xylitol chewing gum and dental caries. Int Dent J 1995;45(suppl 1):65-76.

51 Trahan L: Xylitol: a review of its action on mutans streptococci and dental plaque - its clinical significance. Int Dent J 1955;45 (suppl 1):77-92.

52 Mäkinen KK: The rocky road of xylitol to its clinical application. J Dent Res 2000;79: 1352-1355.

53 Mäkinen KK: New biochemical aspects of sweeteners. Int Dent J 1985;35:23-35.

-54 Tuompo H, Meurman J, Lounatmaa K, Linkola J: Effect of xylitol and other carbon sources on the cell wall of Streptococcus mutans. Scand J Dent Res 1983;91:17-25.

-55 Lee YE, Choi YH, Jeong SH, Kim HS, Lee SH, Song KB: Morphological changes in Streptococcus mutans after chewing gum containing xylitol for twelve months. Curr Microbiol 2009;58:332-337.

56 Mäkinen KK, Scheinin A: Turku sugar studies VII. Principal biochemical findings on whole saliva and plaque. Acta Odontol Scand 1975;33(suppl 70):129-171.

57 Rölla G, Oppermann RV, Bowen WH, Ciardi JE, Knox WH: High amounts of lipoteichoic acids in sucrose-induced plaque in vivo. Caries Res 1980;14:235-238.

58 Mäkinen KK: Latest dental studies on xylitol and mechanism of action of xylitol in caries limitation; in Grenby TH (ed): Progress in Sweeteners. London, Elsevier Applied Science, 1989, pp 331-362.

59 Tanzer JM, Thompson A, Wen ZT, Burne RA: Streptococcus mutans: fructose transport, xylitol resistance, and virulence. J Dent Res 2006;85:369-373.

60 Miyasawa-Hori H, Aizawa S, Takahashi N: Difference in the xylitol sensitivity of acid production among Streptococcus mutans strains and the biochemical mechanism. Oral Microbiol Immunol 2006;21:201-205.

61 Mäkinen KK, Alanen P, Isokangas P, Isotupa K, Söderling E, Mäkinen PL, Wang W, Weijian W, Xiaochi C, Wei Y, Zhang B: Thirty-nine-month xylitol chewing-gum programme in initially 8-year old school children: a feasibility study focusing on mutans streptococci and lactobacilli. Int J Dent 2008;58:41-50.

62 Scheinin A, Mäkinen KK: Turku Sugar Studies I-XXI. Acta Odontol Scand 1975;33 (suppl 70):1-351.

63 Scheinin A, Mäkinen KK, Ylitalo K: Turku Sugar Studies V. Final report on the effect of sucrose, fructose and xylitol diets on the caries incidence in man. Acta Odontol Scand 1975;33(suppl 70):67-104.

64 Galiullin AN: Evaluation of the caries-preventive action of xylitol. Kazan Med J 1981; 67:16-18 (in Russian).
65 Kandelman D, Bär A, Hefti A: Collaborative WHO field study in French Polynesia. I. Baseline prevalence and 32-month caries increment. Caries Res 1988;22:55-62.

66 Scheinin A, Bánóczy J, Szöke J, Esztári I, Pienihäkkinen K, Scheinin U, Tiekso J, Zimmermann P, Hadas E: Collaborative WHO xylitol field studies in Hungary. I. Threeyear caries activity in institutionalized children. Acta Odontol Scand 1985;43:327-347.

67 Scheinin A, Pienihäkkinen K, Tiekso J, Bánóczy J, Szöke J, Esztári I, Zimmermann P, Hadas E: Collaborative WHO xylitol field studies in Hungary. VII. Two-year caries incidence in 976 institutionalized children. Acta Odontol Scand 1985;43:381-387.

68 Kandelman D, Gagnon G: A 24-month clinical study of the incidence and progression of dental caries in relation to consumption of chewing gum containing xylitol in school preventive programs. J Dent Res 1990;69: 1771-1775.

69 Isokangas P, Alanen P, Tiekso J, Mäkinen $\mathrm{KK}$ : Xylitol chewing gum in caries prevention: a field study in children. J Am Dent Assoc 1988; $117: 315-320$.

70 Sintes JL, Escalante C, Stewart B, McCool JJ, García L, Volpe AR, Triol C: Enhanced anticaries efficacy of a $0.243 \%$ sodium fluoride/ xylitol/silica dentifrice: 3-year clinical results. Am J Dent 1995;8:231-235.

71 Sintes JL, Elías-Boneta A, Stewart B, Volpe AR, Lovett J: Anticaries efficacy of a sodium monofluorophosphate dentifrice containing xylitol in a dicalcium phosphate dihydrate base. A 30-month caries clinical study in Costa Rica. Am J Dent 2002;15:215-219.

72 Mäkinen KK, Bennett CA, Hujoel PP, Isokangas PJ, Isotupa KP, Pape HR Jr, Mäkinen PL: Xylitol gums and caries rates: a 40month cohort study. J Dent Res 1995;74: 1904-1913.

73 Mäkinen KK, Hujoel PP, Bennett CA, Isotupa KP, Mäkinen PL, Allen P: Polyol chewing gums and caries rates in primary dentition: A 24-month cohort study. Caries Res 1996; 30:408-417.

74 Mäkinen KK, Pemberton D, Mäkinen PL, Chen CY, Cole J, Hujoel PP, Lopatin D, Lambert P: Polyol-combinant saliva stimulants and oral health in Veterans Affairs patients - an exploratory study. Spec Care Dentist 1996;16:104-115.

75 Alanen P, Isokangas P, Gutmann K: Xylitol candies in caries prevention: results of a field study in Estonian children. Community Dent Oral Epidemiol 2000;28:218-224.

76 Isokangas P, Söderling E, Pienihäkkinen K, Alanen P: Occurrence of dental decay in children after maternal consumption of xy litol chewing gum. J Dent Res 2000;79:18851889.

7 Machiulskiene V, Nyvad B, Baelum V: Caries-preventive effect of sugar-substituted chewing gum. Community Dent Oral Epidemiol 2001;29:278-288.
Hayes C: Xylitol gum decreases the decayed, missing, and filled surfaces (DMFS) score over a 3-year period by an average of 1.9. J Evid Based Dent Pract 2002;2:14-15.

79 Thorild I, Lindau B, Twetman S: Effect of maternal use of chewing gums containing xylitol, chlorhexidine or fluoride on mutans streptococci colonization in the mothers' infant children. Oral Health Prevent Dent 2003; 1:53-57.

80 Thorild I, Lindau B, Twetman S: Caries in 4-year-old children after maternal chewing of gums containing combinations of xylitol, sorbitol, chlorhexidine, and fluoride. Eur Arch Pediatr Dent 2006;7:241-245.

81 Honkala E, Honkala S, Shyama M, Al-Mutawa SA: Field trial on caries prevention with xylitol candies among disabled school students. Caries Res 2006;40:508-513.

-82 Aaltonen AS, Suhonen JT, Tenovuo J, InkiläSaari I: Efficacy of a slow-release device containing fluoride, xylitol and sorbitol in preventing infant caries. Acta Odontol Scand 2000;58:285-292.

83 Hausen H, Seppä L, Poutanen R, Niinimaa A, Lahti S, Kärkkäinen S, Pietilä I: Noninvasive control of dental caries in children with active initial lesions. A randomized clinical trial. Caries Res 2007;41:384-391.

84 Isokangas P, Tiekso J, Alanen P, Mäkinen KK: Long-term effect of xylitol on dental caries. Community Dent Oral Epidemiol 1989; 17:200-203.

-85 Isokangas P, Tenovuo J, Söderling E, Männistö $\mathrm{H}$, Mäkinen KK:. Dental caries and mutans streptococci in the proximal areas of molars affected by the habitual use of xylitol chewing gum. Caries Res 1991;25:444448.

86 Isokangas P, Mäkinen KK, Tiekso J, Alanen P: Long-term effect of xylitol chewing gum in the prevention of dental caries: a follow-up 5 years after termination of a prevention program. Caries Res 1993;27:495-498.

87 Virtanen JI, Bloigu RS, Larmas MA: Timing of first restorations before, during, and after a preventive xylitol trial. Acta Odontol Scand 1996;54:211-216.

>8 Mäkinen KK, Hujoel PP, Bennett CA, Isokangas P, Isotupa K, Pape HR Jr, Mäkinen PL: A descriptive report of the effects of a 16-month xylitol chewing-gum programme subsequent to a 40 -month sucrose gum programme. Caries Res 1998;32:107-112.

89 Hujoel PP, Mäkinen KK, Bennett CA, Isotupa KP, Isokangas PJ, Allen P, Mäkinen PL: The optimum time to initiate habitual xylitol gum-chewing for obtaining long-term caries prevention. J Dent Res 1999;78:797-803.

90 Leach SA, Green RM: Effect of xylitol-supplemented diets on the progression and regression of fissure caries in the albino rat. Caries Res 1980;14:16-23.

91 Shyu KW, Hsu MY: The cariogenicity of xylitol, mannitol, sorbitol, and sucrose. Proc Natl Sci Counc ROC 1980;4:21-26. 
-92 Havenaar R, Huis in't Veld JHJ, de Stoppelaar JD, Backer Dirks O: Anti-cariogenic and remineralizing properties of xylitol in combination with sucrose in rats inoculated with Streptococcus mutans. Caries Res 1984;18:269-277.

$>93$ Nakai Y, Shinga-Ishihara C, Kaji M, Moriya K, Murakami-Yamanaka K, Takimura M: Xylitol gum and maternal transmission of mutans streptococci. J Dent Res 2010;89: 56-60.

94 Raunhardt O, Ritzel G: Xylitol-clinical investigations in humans. Int J Vitam Nutr Res 1982(suppl 22):5-88.

95 US Department of Health and Human Services. Health aspects of sugar alcohols and lactose (Report prepared for Food Safety and Applied Nutrition, Food and Drug Administration. Contract No. FDA 223-832020). Life Sciences Research Office, FASEB, Bethesda, 1986.

96 World Health Organization: Evaluation of certain food additives and contaminants. Twenty-seventh Report of the Joint FAO/ WHO Expert Committee on Food Additives. WHO Tech Rep Ser 1983;696:23-34, 45.

97 Mäkinen KK: Dietary prevention of dental caries by xylitol - clinical effectiveness and safety. J Appl Nutr 1992;44:16-28.

$\checkmark 98$ Hamilton IR, Ellwood DC: Effects of fluoride on carbohydrate metabolism by washed cells of Streptococcus mutans grown at various $\mathrm{pH}$ values in a chemostat. Infect Immun 1978;19:434-442.

$>99$ Arends J, Smits M, Ruben JL, Christoffersen J: Combined effect of xylitol and fluoride on enamel demineralization in vitro. Caries Res 1990;24:256-257.

$\checkmark 100$ Luoma H, Murtomaa H, Nuuja T, Nyman A, Nummikoski P, Ainamo J, Luoma AR: A simultaneous reduction of caries and gingivitis in a group of schoolchildren receiving chlorhexidine-fluoride applications. Results after 2 years. Caries Res 1978;12:290298.

101 Meurman JH: Ultrastructure, growth and adherence of Streptococcus mutans after treatment with chlorhexidine and fluoride. Caries Res 1988;22:283-287.

102 Rogers AH, Bert AG: Effects of xylitol and fluoride on the response to glucose pulses of Streptococcus mutans T8 growing in continuous culture. Oral Microbiol Immunol 1992;7:124-126.

103 Maehara H, Iwami Y, Mayanagi H, Takahashi N: Synergistic inhibition of fluoride and xylitol on glycolysis by mutans streptococci and its biochemical mechanism. Caries Res 2005;39:521-528.

104 Petin VG, Kim JK, Kritsky RO, Komarova LN: Mathematical description, optimization and prediction of synergistic interaction of fluoride and xylitol. Chemosphere 2008;72:844-849.
105 Kim SS, Kim S, Kim E, Hyun B, Kim KK, Lee BJ: Synergistic inhibitory effect of cationic and antimicrobial agents on the growth of oral streptococci. Caries Res 2003;37:425-430.

106 Decker EM, Maier G, Axmann D, Brecx M, von Ohle C: Effect of xylitol/chlorhexidine versus xylitol or chlorhexidine as single rinses on initial biofilm formation of cariogenic streptococci. Quintessence Int 2008; 39:17-22.

107 Han SJ, Jeong SY, Nam YJ, Yang KH, Lim HS, Chung J: Xylitol inhibits inflammatory cytokine expression induced by lipopolysaccharide from Porphyromonas gingivalis. Clin Diagn Lab Immunol 2005;12:12851291.

108 Eisenberg AD, Young DA, Fanhsu J, Spitz LM: Interactions of sanguinarine and zinc on oral streptococci and Actinomyces species. Caries Res 1991;25:185-190.

109 Drake DR, Grigsby W, Cardenzana A, Dunkerson D: Synergistic, growth-inhibitory effects of chlorhexidine and copper combinations on Streptococcus mutans, Actinomyces viscosus, and Actinomyces näslundi. J Dent Res 1993;72:524-528.

110 Klepek YS, Volke M, Konrad KR, Wippel K, Hoth S, Hedrich R, Sauer N: Arabidopsis thaliana polyol/monosaccharide transporters1 and 2: fructose and xylitol/ $\mathrm{H}^{+}$ symporters in pollen and xylem cells. J Exp Bot 2010;61:537-550.

111 Mäkinen KK: Public endorsement and use of xylitol for caries prevention with special reference to Finnish Health Centre programmes. Finn Dent J 2006;13(suppl 1):6675.

112 Turtola L: A trial of adding xylitol chewing gum to a part of university students' meals. Fin Stud Health Serv Treatises 1990;30 (in Finnish with English summary).

113 Murtomaa H, Vuopio T, Turtola L: The use of xylitol chewing gum in oral health Promotion for Finnish students. Health Promotion Int 1993;8:271-274.

114 Nordblad A, Suominen-Taipale L, Murtomaa H, Vartiainen E, Koskela K: Smart Habit Xylitol Campaign, a new approach in oral health promotion. Community Dent Health 1995;12:230-234.

115 Kovari H, Pienihäkkinen K, Alanen P: The use of xylitol chewing gum in kindergartens. A follow-up study in Savonlinna, Finland. Acta Odontol Scand 2003;61:367-370.

116 Honkala E, Rimpelä A, Karvonen S, Rimpelä M: Chewing of xylitol gum - a well adopted practice among Finnish adolescents. Caries Res 1996;30:34-39.
117 Honkala S, Honkala E, Tynjälä J, Kannas L: Use of xylitol chewing gum among Finnish schoolchildren. Acta Odontol Scand 1999; 57:306-309.

118 Slack GL, Millward E, Martin WJ: The effect of tablets stimulating salivary flow on the incidence of dental caries. Br Dent J 1964;116:105-108.

119 Möller IJ, Poulsen S: The effect of sorbitolcontaining chewing gum on the incidence of dental caries, plaque and gingivitis in Danish schoolchildren. Community Dent Oral Epidemiol 1973;1:58-67.

120 Frostell G, Blomlöf L, Blomqvist T, Dahl GM, Edward S, Fjellström Å, Henrikson CO, Larje O, Nord CE, Nordenvall KJ: Substituiton of sucrose by Lycasin ${ }^{\circledR}$ in candy. 'The Roslagen study'. Acta Odontol Scand 1974;32:235-254.

121 Bánóczy J, Hadas É, Esztári I, Marosi I, Fözy L, Szántó S: Dreijährige Erfahrungen mit Sorbit im klinischen Längsschnitt-Versuch. Kariesprophylaxe 1980:2;39-46.

122 Glass RL: A two-year clinical trial of sorbitol chewing gum. Caries Res 1983:17;365368 .

123 Szöke J, Bánóczy J, Proskin HM: Effecet of after-meal sucrose-free gum chewing on clinical caries. J Dent Res 2001;80:1725-1729.

124 Kawanabe J, Hirasawa M, Takeuchi T, Oda T, Ikeda T: Noncariogenicity of erythritol as a substrate. Caries Res 1992;26:358-362.

125 Mäkinen KK, Isotupa KP, Kivilompolo T, Mäkinen PL, Toivanen J, Söderling E: Comparison of erythritol and xylitol saliva stimulants in the control of dental plaque and mutans streptococci. Caries Res 2001;35: 129-135.

126 Mäkinen KK, Isotupa KP, Kivilompolo T, Mäkinen PL, Murtomaa S, Petäjä J, Toivanen J, Söderling E: The effect of polyol-combinant saliva stimulants on S. mutans levels in plaque and saliva of patients with mental retardation. Spec Care Dentist 2002;22:187-193.

127 Mäkinen KK, Saag M, Isotupa KP, Olak J, Nõmmela R, Söderling E, Mäkinen PL: Similarity of the effects of erythritol and xylitol on some risk factors of dental caries. Caries Res 2005;39:207-215.

128 Mäkinen KK: Xylitol-associated remineralization of caries lesions. Oralprophylaxe Kinderzahnheilk 2009;31:66-75.

129 Burt BA: The use of sorbitol- and xylitolsweetened chewing gum in caries control. J Am Dent Assoc 2006;137:190-196.

130 Deshpande A, Jadad AR: The impact of polyol-containing chewing gums on dental caries: a systematic review of original randomized controlled trials and observational studies. J Am Dent Assoc 2008;139:1602-1614.

-131 Milgrom P, Ly KA, Rothen M: Xylitol and its vehicles for public health needs. Adv Dent Res 2009;21:44-47. 